\title{
Hoop House Gardening in the Wapekeka First Nation as an Extension of Land-Based Food Practices
}

\author{
Heather A. Thompson, ${ }^{1,2}$ Courtney W. Mason ${ }^{3}$ and Michael A. Robidoux ${ }^{1}$
}

(Received 12 February 2018; accepted in revised form 27 June 2018)

\begin{abstract}
Rural Indigenous communities in Canada's North face many challenges getting regular access to nutritious foods, primarily because of the high cost of market food, restricted availability of nutritious foods, and lack of government support for nutritious food programs. The consequences of food insecurity in this context are expressed in high rates of diabetes, heart disease, and childhood obesity. Many Indigenous communities are responding to issues related to healthy food access by attempting to rebuild local food capacity in their specific regions. Important first steps have been taken in developing local food initiatives, yet whether these initiatives are improving northern food security remains to be seen. We explore this question by working with the Oji-Cree First Nation in the community of Wapekeka, northern Ontario, to construct a hoop house and develop a school-based community gardening program. Using a community-based participatory approach, we determined that hoop house and gardening initiatives in rural, northern settings have the potential to build up local food production, develop the skills and knowledge of community members, engage youth in growing local food, and align with land-based food teachings. We show that despite widespread and multidimensional community hardships, there was considerable community buy-in and support for the project, which gives hope for future development and provides important insight for those seeking to initiate similar gardening, hoop house, or greenhouse initiatives in northern Indigenous communities.
\end{abstract}

Key words: Canada; Wapekeka First Nation; food security; local food systems; hoop house; greenhouses; gardening; Indigenous health; sustainability; traditional food

RÉSUMÉ. Les collectivités autochtones du Canada en milieu rural nordique ont de nombreux défis à relever pour avoir régulièrement accès à de la nourriture nutritive, principalement en raison du coût élevé des denrées alimentaires du marché, de la disponibilité restreinte d'aliments nutritifs et du manque de soutien gouvernemental pour l'adoption de programmes de provisions alimentaires nutritives. Dans ce contexte, les conséquences de l'insécurité alimentaire s'expriment par des taux élevés de diabète, de maladies du cœur et d'obésité infantile. De nombreuses collectivités autochtones relèvent les défis d'accès à des denrées saines en tentant de renforcer la capacité alimentaire locale de leurs propres régions. Ils ont déjà pris d'importantes mesures pour aboutir à des initiatives alimentaires locales, mais il reste à voir si ces initiatives permettent d'améliorer la sécurité alimentaire dans le Nord. Nous nous penchons sur cette question de concert avec la Première Nation oji-cri dans la collectivité de Wapekeka, dans le nord de l'Ontario, en construisant plus précisément une serre à arceaux et en aménageant un programme de jardinage scolaire. Grâce à notre approche participative et communautaire, nous avons déterminé que la serre à arceaux et les initiatives de jardinage en milieu rural nordique ont la possibilité de se traduire par l'accumulation d'aliments produits à l'échelle locale, de favoriser l'acquisition de compétences et de connaissances, d'inciter les jeunes à cultiver des aliments localement et de mettre en valeur les enseignements relatifs à la nourriture provenant de la terre. Nous montrons que malgré les difficultés multidimensionnelles répandues dans la collectivité, ce projet a suscité un appui considérable de la part des gens, ce qui donne de l'espoir en vue de développements futurs et permet aux personnes désirant mettre en œuvre des initiatives semblables de jardinage, de serres à arceaux et de serres ordinaires dans les collectivités autochtones nordiques d'acquérir d'importantes connaissances.

Mots clés : Canada; Première Nation de Wapekeka; sécurité alimentaire; systèmes alimentaires locaux; serre à arceaux; serres; jardinage; santé des Autochtones; durabilité; nourriture traditionnelle

Traduit pour la revue Arctic par Nicole Giguère

\footnotetext{
${ }^{1}$ Indigenous Health Research Group, School of Human Kinetics, University of Ottawa, 75 Laurier Ave East, Ottawa, Ontario K1N 6N5, Canada;

${ }^{2}$ Corresponding author: hthom023@uottawa.ca

${ }^{3}$ Rural Livelihoods and Sustainable Communities, Thompson Rivers University, 805 TRU Way, Kamloops, British Columbia V2C 0C8, Canada

(C) The Arctic Institute of North America
} 


\section{INTRODUCTION}

Indigenous peoples of what is now known as Canada have experienced dietary and lifestyle transformations that have resulted in exceedingly high rates of food insecurity and diet-related disease (Willows, 2005; Damman et al., 2008; Elliott et al., 2012). Food security includes having physical and economic access to sufficient, nutritious, and safe foods (WHO, 1996). The consequences of food insecurity in this context contribute to high rates of diabetes, heart disease, and childhood obesity (Haman et al., 2010). Factors that amplify food insecurity in rural communities of the North include poverty (Kuhnlein and Receveur, 1996; Willows et al., 2009); the high cost and low availability of quality, healthy market food (Power, 2008; Ford, 2009; Socha et al., 2012); the lack of government support for nutritious food programs (Skinner et al., 2013); the loss of traditional knowledge; and reduced access to traditional lands (Power, 2008). A growing understanding of the role that traditional (or culturally appropriate) foods play in the diet of Indigenous peoples has motivated an interest in expanding the definition of food security (Walch et al., 2018).

Local food procurement via traditional food systems is often suggested as a strategy for improving diet quality. Northern traditional or country food security is defined as "the continued and predictable availability and access to food derived from northern environments through Indigenous cultural practices" (Paci et al., 2004:1). Many Indigenous communities are responding to issues affecting healthy food access by attempting to rebuild local food capacity in their specific regions. For the purpose of this article, the term "traditional food system" is used to identify all food accepted within a particular culture that is available from local resources, such as hunting or fishing. The term encompasses aspects such as sociocultural meanings and acquisition and processing techniques. While these modes of food procurement are undoubtedly important, research indicates that for rural and northern communities, the net cost of traditional foods procured from the land is comparable to that of food purchased from the store, or even more expensive, and thus these methods often fall short when it comes to improving population health (Robidoux et al., 2012; Pal et al., 2013). In addition to hunting and fishing initiatives, the adoption of sustainable agriculture in the form of community gardening and greenhouses is slowly emerging as an alternative solution to the unavailability of nutritious market and hunted or gathered foods in many communities (Stroink and Nelson, 2009; Socha et al., 2012; Spiegelaar and Tsuji, 2013).

Local, sustainable, micro-scale food production that gives control back to the community is being developed in various forms as part of the solution to food insecurity. Such initiatives point to options outside of commercial agriculture and suggest that subsistence food production can increase food autonomy as communities gain more control over their food systems. In this analysis, guided by participatory research methods, we focus on a small-scale community gardening initiative in a remote fly-in First Nation community in northwestern Ontario. The key objective was to assess the general viability of the hoop house gardening initiative in the community and consider what role it might play in improving local food security. Hoop houses are simple, minimally climate-controlled, greenhouse-like structures over bare ground that rely on passive solar heating (Russo and Shrefler, 2012). By using a community-based participatory approach to construct a hoop house for local gardening, researchers and community leaders sought to understand how feasible a hoop house is in the community, what barriers to and facilitators of community gardening initiatives exist in this setting, and finally, whether the community would accept the hoop house as complementary to traditional food practices.

\section{FOOD CRISIS IN THE NORTH}

While many factors have contributed to the food challenges northern Indigenous peoples face, colonization radically transformed local Indigenous food systems in Canada. Colonialism, referring to the European colonization of distant lands that started in the late 15th century, is understood as the establishment of foreign rule over a dependent country, territory, or people. It is generally associated with imperial powers, the legal domination over a subordinate people, the exploitation of human and natural resources, and the redistribution of these resources to benefit imperial interests (Kroll-Zeldin, 2016). Even today, communities are still trying to recover from the impacts of colonial legislation, structural influences, and tactics of assimilation perpetuated by the Canadian government in the 20th century (Czyzewski, 2011). The aspect of colonization most relevant in this context was the processes by which colonial policies undermined Indigenous food systems. By disrupting and often eradicating land-based food practices (Leblanc and Burnett, 2017), these policies forced a dependency on highly processed market foods that lack nutrient density (Kuhnlein and Receveur, 1996; Batal et al., 2005; Bersamin et al., 2007; Pal et al., 2013).

Colonialism was and continues to be systemic and multidimensional. Two major policies were responsible for most subjugation of knowledge about traditional foodways. First, the government restricted Indigenous peoples' ability to pursue traditional subsistence practices by initiating the reserve system and introducing a series of repressive policies that directly targeted these practices, eventually making them illegal in many regions in Canada (Alfred, 2009). These government actions conflicted with the efforts of many Indigenous groups throughout the country who sought to preserve their ability to hunt, fish, and gather by signing treaties that protected these rights in the court of law. Many governments disregarded these rights in the following decades by implementing policies that restricted Indigenous peoples' ability to use and manage their lands as they had for centuries, or in some cases, 
millennia (Alfred, 2009). Second, the government created the residential school system as an assimilation strategy to prevent Indigenous environmental, cultural, and linguistic knowledge from being passed down from one generation to the next (Miller, 1996; Chrisjohn and Young, 1997; Milloy, 1999; Streit and Mason, 2017). Not only were generations of children forcibly separated from their parents, but they were also taught that their way of living off the land was uncivilized and underdeveloped and needed to be replaced by Western forms of agriculture (Chrisjohn and Young, 1997; Leblanc and Burnett, 2017). Further, there is evidence that in Ontario the schools used labour on their garden plots as punishment: for various infractions, schoolchildren would be subjected to hours of intense labour, weeding, digging, and carrying water, which created damaging associations with gardening (Leblanc and Burnett, 2017). The aim of almost all early legislation and colonial action in Canada was to force Indigenous peoples to assume a EuroCanadian lifestyle and form of governance.

The colonial narrative of economic development forced communities away from local subsistence and pushed them towards using the land for profit and capital exchange (Loring and Gerlach, 2010; Leblanc and Burnett, 2017). In the region of our study, the European fur trade built new relationships between Indigenous peoples and Europeans, which led to the incorporation of Indigenous communities into a budding capitalist economy (Krech, 1984). Increasing involvement in the fur trade altered the political economy of Indigenous communities; animal resources were being harvested for capital exchange rather than purely for subsistence or material needs. These new demands on local animal populations (for fur, hides, and meat) eventually depleted critical food sources, reducing people's ability to feed themselves or profit economically from these sources (Leblanc and Burnett, 2017). Development of the fur trade was the driving force behind land-grabbing and the subjugation of traditional foodways. However, despite the interventions that eroded local food systems and altered food practices, there is a distinct possibility that gardens could be integrated into communities' subsistence strategies today in a way that reflects local knowledge (Loring and Gerlach, 2010). While traditional gardening for subsistence practices did not fit the archetype of Western agriculturalists, there is evidence that many communities have used local cultivation effectively to fill an important niche in local foodways since the turn of the 20th century (Loring and Gerlach, 2010). However, the creation of a long-term dependency on the government has irreversibly eroded traditional food systems, shifting them towards a Western, market-based diet (Morrison, 2011; Rudolph and McLachlan, 2013).

In Indigenous communities the shift from one food system to another is referred to as a "nutrition transition" (Samson and Pretty, 2006). It is characterized by a rapid westernization of diet and lifestyle and associated with rising prevalence of chronic disease (Damman et al., 2008). Dietary westernization has been defined as the diffusion and adoption of Western food culture (Uusitalo et al., 2005). For Indigenous peoples, this shift tends to imply reduced consumption of foods accessed through land-based procurement, such as hunting, fishing, and gathering, and increased reliance on processed foods and drinks that are high in refined carbohydrates and saturated fat (Batal et al., 2005; Haman et al., 2010). Remote northern food systems include both traditional (or land-based) foods and market (or store-bought) foods in varying proportions. Northern Indigenous communities typically rely on the Northern Store (owned by the Northwest Company) for market food items. Prices of this provider are often exorbitant, in part because of the high costs of food transport and the monopoly providers exercise in the remote regions where they operate (Lambden et al., 2006; Haman et al., 2010; Robidoux et al., 2012; Pal et al., 2013). The excessive costs make it difficult for northern residents to purchase nutritious foods, which are often scarce in northern stores. The challenges these communities face have sparked political and academic movements that attempt to define and combat issues regarding northern food access.

\section{Food Security and Food Sovereignty}

At the World Health Summit of 1996, the World Health Organization (WHO) defined food security as existing "when all people, at all times, have physical and economic access to sufficient safe and nutritious food that meets their dietary needs and food preferences for an active and healthy life" (WHO, 1996). This definition takes into account the physical availability of food, economic and physical access to food, and food utilization, meaning the energy and nutrient content of foods (Power, 2008). Food security is a useful concept for addressing issues of hunger and malnutrition across the globe. However, it operates under the assumption that solutions to hunger are economically driven, and enacted by a privileged few. The term "food security" does not consider gaining more control over food systems locally or take historical injustices and cultural aspects of food issues into account. Thus, scholars and food activists increasingly employ the term "food sovereignty," coined by La Via Campesina in 1996, in order to bypass such capitalistic and neoclassical economic thinking (Leblanc and Burnett, 2017).

The notion of food sovereignty is continually evolving, but at its core is a set of objectives based on strengthening community and increasing social and environmental sustainability in the production, consumption, and distribution of nutritious and culturally appropriate food (Desmarais and Wittman, 2014). In contrast to the food security framework, food sovereignty places more control into the hands of those who have been systematically excluded from the formulation of food policy and places them at the center of decisions on food systems (Coxall, 2014). The concept of food sovereignty is useful within an Indigenous context because it offers a way of thinking about reasserting control over one's food. This framework 
recognizes that Indigenous peoples living in northern Canada suffer from the cumulative impacts of many deliberate disruptions to their sovereignty. Food sovereignty in Canada stresses the importance of decolonization, self-determination, and the inclusion of local subsistence practices as key elements of sustainable food systems (Morrison, 2011).

\section{Land-Based Food Efforts}

Local subsistence practices in northern Indigenous communities typically involve traditional foods that are hunted, gathered, or fished. Many constraints, such as lack of time, money, or resources, surround traditional harvesting practices (Robidoux and Mason, 2017). Further, the North is experiencing many rapid socioeconomic and ecological changes that relate to climate change (Ford, 2009; Brinkman et al., 2016). Climate change has affected the abundance of wild game both directly and indirectly through impacts on the distribution of fish and game species (Loring and Gerlach, 2010; Wesche and Chan, 2010). Indigenous peoples' reliance on local wild resources means that climate impacts on ecosystems have a particularly important effect on subsistence. Dependence on regional ecosystems also leaves Indigenous peoples vulnerable to the impacts of contaminants and pathogens on the quality of subsistence foods (Seabert et al., 2013). Regional ecosystems in Canada are incredibly diverse, so blanket solutions that attempt to improve local food access using traditional harvesting practices vary in effectiveness and are often ineffective. What works to revitalize traditional food practices in one area may not be effective for a neighboring community, or even in a subsequent year. As a result, some Indigenous peoples in Canada are adopting alternative food strategies that involve non-traditional food procurement methods. One such example is subsistence agriculture, which can involve agroforestry, community gardens, greenhouses, and wild berry harvesting (Skinner et al., 2014). This paper focuses on how the introduction of a small-scale community hoop house garden might help increase access to nutritious food.

Few published studies have focused on gardening initiatives with Indigenous groups in Canada (Lombard et al., 2006; Viola, 2006; Fieldhouse and Thompson, 2012; Barbeau et al., 2015), but those that do so suggest that local food production is a viable strategy to improve food security (Fieldhouse and Thompson, 2012). For many northern Indigenous communities, gardening without a greenhouse or hoop house may not be feasible because of climatic conditions such as permafrost and short growing seasons (Skinner et al., 2014). Skinner et al. (2014), reporting on a community greenhouse project in the Fort Albany First Nation in northern Ontario, conclude that while the amount of food grown in their community greenhouse would not be able to sustain many people overall, the space could be used to address issues of food access by other means, such as germinating seeds to cultivate home-based gardens.
The researchers argue that incorporating gardening in Indigenous communities builds the knowledge and skills of community members and helps to improve their social and physical environment (Viola, 2006; Skinner et al., 2014). Similarly, the Inuit in Hopedale, Nunatsiavut, addressed the limited supply of nutritious foods available in their community by implementing the Hopedale Community Garden Program, which also addressed climatic barriers by germinating seeds prior to planting them in their community garden (Our Food in Nunavut, 2015). Ultimately, initiatives such as these can address issues that affect access to food by giving control back to the communities themselves and play a part in reducing diet-related disease (Lombard et al., 2006). However, the feasibility of such projects depends entirely on context; each community will have distinct abilities and needs, and what works in one community will not necessarily translate to another. Each community also has its own history of colonization and destruction of traditional food systems. The spatial and temporal land uses that are most traditional vary, and integration of gardening must reflect local knowledge, awareness, and responsiveness to unique ecosystems (Loring and Gerlach, 2010). Further, long-term involvement is necessary to see how the project works over time, which means there must be a long-term commitment from external partners and funding sources to ensure sustainability. Thus, it is critical to foster longstanding and sustainable relationships between individual communities and key stakeholders.

\section{RESEARCH CONTEXT}

The Indigenous Health Research Group (IHRG) at the University of Ottawa has been working and building relationships in this area of northern Ontario for the past decade. The multidisciplinary group of researchers originally partnered with the Nishnawbe Aski Nation (NAN) in 2006 and has continued to foster relationships in the region ever since (Robidoux and Mason, 2017). The present project was supported by the Michaëlle Jean Centre for Global and Community Engagement and by research members of the IHRG. The authors applied for funding for the project in January 2017, after discussions with Wapekeka First Nation leaders about possible strategies to address community food challenges. In February 2017, funding was secured from the Students for Canada's North scholarship and the Alex Trebek Challenge and Innovation Fund (Michaëlle Jean Centre funding programs), and initial planning for a community hoop house garden was set in motion.

\section{Study Location}

This study took place in Wapekeka (Fig. 1), an Oji-Cree First Nation located in northwestern Ontario between $50^{\circ}$ and $55^{\circ} \mathrm{N}$ (INAC, 2017a). The community has a registered 


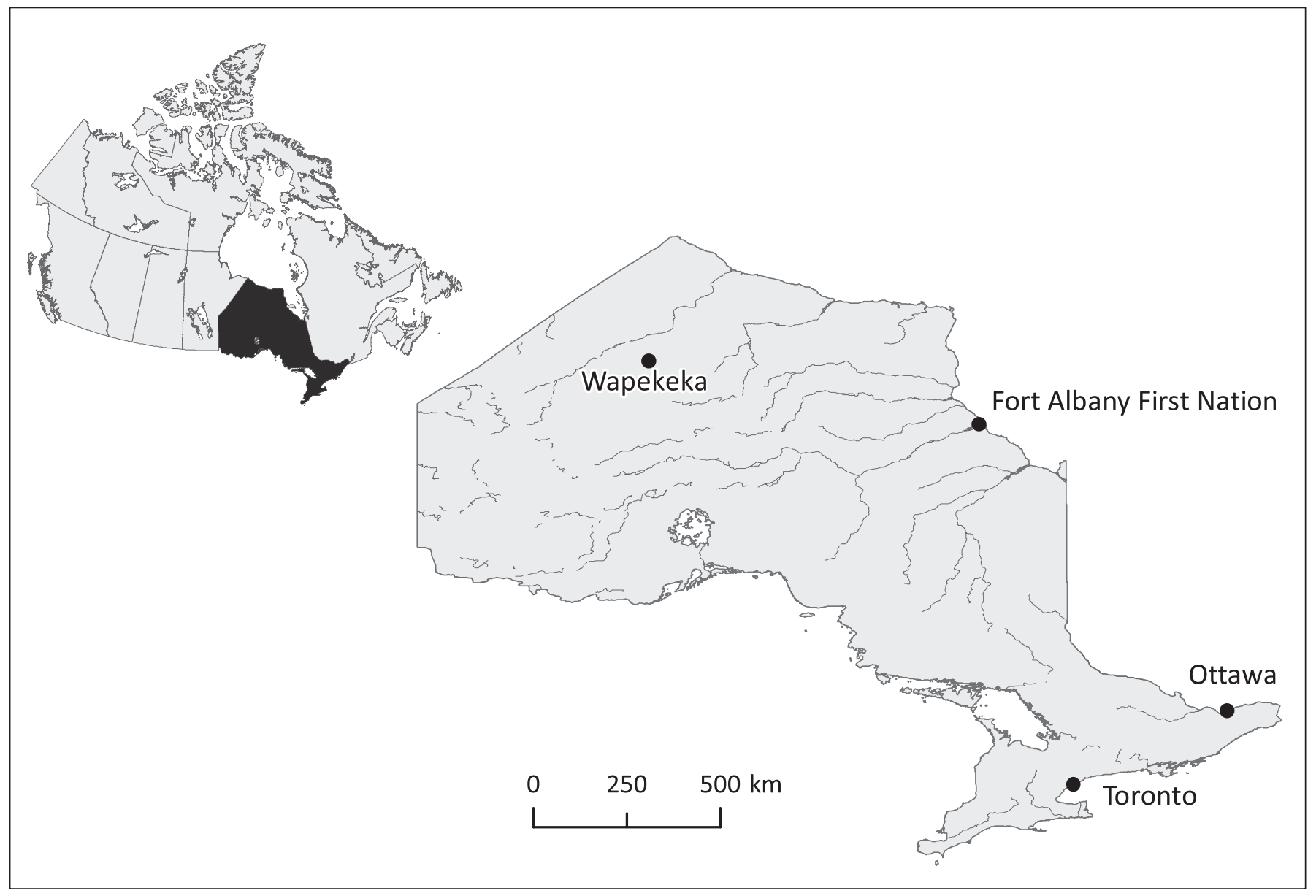

FIG. 1. "Ontario Community Map" identifies the names and locations of the Wapekeka First Nation community profiled in this article. Map created by Sarah Simpkin, University of Ottawa.

population of 369 (INAC, 2017b). For the Ojibwa, Cree, and Oji-Cree people in this region, government intervention officially began in 1906, with the signing of Treaty 9 (Pal et al., 2013). After adhesions were made to Treaty 9 in 1932, permanent settlements and stores were established. The Wapekeka First Nation is geographically remote, with access by plane year-round and access by a snow/ ice road after freeze-up. The traditional food system of hunting, fishing, and gathering that sustained community members in this region in the past has been degraded by colonization, climate change, environmental contaminants, and a heavy reliance on the market food system. Over the last few decades, the number of hunters in the community has severely declined: only about 10 households still have individuals that hunt year-round (Leibovitch Randazzo and Robidoux, 2018). There is one store in the community that has basic food and household items. Fresh produce, when available, is often in poor condition and extremely expensive. More store food options are available at slightly lower costs to those community members who have the means to travel by truck 30 minutes over a rugged road to the neighbouring community of Kitchenuhmaykoosib Inninuwug (Big Trout Lake), but food items are still limited and expensive compared to the closest urban centers of Sioux Lookout or Thunder Bay (Robidoux and Mason, 2017; Leibovitch Randazzo and Robidoux, 2018).

\section{METHODS}

This project used a research design that the IHRG has been using for the past decade in their research with diverse Indigenous communities (Robidoux and Mason, 2017). The research is informed by Indigenous research methodologies. In order to support two-directional learning and lateral sharing of information, researchers fostered pre-existing connections and relationships in the community (Simpson, 2014). The researchers for this project do not share Indigenous heritage or identity and do not wish to overstate their ability to use Indigenous methods. However, the longstanding partnership with the IHRG and the Wapekeka First Nation has been critical in shaping how researchers have come to work with the leadership and other members of the community. Throughout all stages of the project, researchers actively engaged with community leadership and community project members to determine the scope 
and direction of the research. Participants signed consent forms that included the option for their identities to remain anonymous. The option to use real names was also included because we felt it fitting to give credit to the outstanding work of the many volunteers and participants involved in the project. Only one quoted participant wished to remain anonymous. All research activities underwent ethics review by the University of Ottawa's Research Ethics Board.

\section{Community-based Participatory Research}

Starting well before the onset of the hoop house construction, the team utilized a community-based participatory research (CBPR) approach to identify, prioritize, and address concerns and to bridge knowledge gaps between communities and academics (Ablah et al., 2016). While this approach is often used in health equity research (Stanley et al., 2015; Frerichs et al., 2016), many of its key concepts can also help us to understand the diverse perspectives of community members and the complexities of local or regional issues of food access, security, and sovereignty. CBPR promotes active collaboration and has been increasingly used to engage effectively with communities suffering from health disparities (in comparison to non-Indigenous populations in Canada) (Townsend et al., 2015; Frerichs et al., 2016). In this project, the researchers worked in partnership with Wapekeka First Nation leaders and health officials to identify key concerns related to food challenges and initiate a garden built with and for community members. A CBPR approach within greenhouse or gardening projects creates avenues for building individual and community empowerment whereby program champions and community members are able to take control of initiatives that they feel are worthwhile (Skinner et al., 2014). Our approach allowed researchers and community members to exchange traditional knowledge, science knowledge, and varied skills and expertise to address a complicated problem.

CBPR has become an important framework for engaging in research with Indigenous peoples (McHugh and Kowalski, 2009; McHugh et al., 2013; Townsend et al., 2015). However, there were challenges to using this approach as well. The project required considerable financial and time investment up front. It was a long, slow process that required ongoing development of relationships and trust between community members and researchers. Fletcher (2003) argues that there is not one single process to engage in CBPR, but it is necessary to ensure that community partners are engaged in all phases of the research. The research team relied heavily on preexisting relationships with community members, and while the hoop house project itself lasted approximately six months, it was a part of a much larger ongoing effort to address health challenges in the Wapekeka First Nation. The primary advantage for using a CBPR approach is its ability to identify the specific knowledge and perspectives that a diverse group of community members may represent.
In addition to stimulating action-oriented results, this type of research is very conducive to the development of policy that benefits individuals and communities as it better reflects their needs and experiences (Jagosh et al., 2015). As outlined below, the CBPR approach also aligns well with a variety of mixed methods from the social sciences and humanities.

\section{Fieldwork Observations}

The fieldwork for this project involved a mixed methods approach that included semi-structured interviews with local food champions and community members, as well as participant observation. The hoop house was assembled in May 2017 and gardening activities were planned shortly thereafter. Researchers left the community a week before planting took place, but while still there, they worked along with participants to help in making decisions and constructing the hoop house. Observations made by the research team were recorded in detailed field notes. The first author also kept a daily reflective journal during community visits in order to capture the context in which the participants live (DeWalt and DeWalt, 2002; Ortlipp, 2008). Research members made two visits to the community, one in May and the other in September 2017, each lasting between two and three weeks. Interviews were conducted during the September trip only, after the hoop house had been operating throughout the summer. The purpose of the first visit was to help construct the hoop house, prepare the garden beds, and plant seeds, whereas the second visit was largely to follow up with the community partners, assist in the harvest, and prepare the garden beds for the following growing season. In addition, the second trip allowed researchers to speak with community leadership, food champions, and other community members about the hoop house project, the yields, successes or barriers, lessons learned, and potential steps needed to move forward with the project and improve it.

\section{Semi-structured Interviews}

The research team returned to the community in September 2017 to conduct informal semi-structured interviews with knowledgeable community members (Whiting, 2008). A few households in Wapekeka still maintain traditional or land-based subsistence practices (Leibovitch Randazzo and Robidoux, 2018), and these community members were part of the project design from the start. Initially, five adult participants were selected because of their connection to the hoop house or their involvement with conceptualizing the project, building the structure, planting seeds, or caring for the garden and plants throughout the summer. Snowball sampling helped to identify seven additional participants. In total, we interviewed 12 participants aged $25-45$, seven males and five females. 
The interview schedule was flexible, open-ended, and centered on the theme of the hoop house. During previous work in this community, researchers had noted that using an audio-recorder during interviews seemed to make interviewees feel uncomfortable and less forthright when answering questions (Robidoux et al., 2012; Pal et al., 2013). We therefore decided to use a conversational style of interview conducted by two researchers, one leading the interview and the second taking detailed notes. By the end of the interviews, it appeared that in this more casual interview setting, participants generally did feel comfortable discussing the topics that were raised. Members of the community referred to the hoop house simply as "the greenhouse" and this term was used in both our interview questions and participant responses. The interviews began with open-ended questions (e.g., "What did you think of the greenhouse?") and followed up with questions such as "What did you like best about it?" The conversations eventually shifted to traditional food and traditional food practices. After general questions, such as "What do you consider to be traditional food?", this line of questioning eventually led to whether or not the participant thought foods grown in the hoop house would be in line with traditional foods. The formal interviews lasted from 10 to 45 minutes.

To help us understand how the community perceived the viability of the hoop house garden project and its intersection with traditional food practices, we also held informal conversations about traditions and traditional foods with community members who were directly involved in the greenhouse project and in local subsistence practices. Researchers fostered pre-existing connections and relationships to support two-way learning and sharing of information. These informal conversations, or "visits" with community members, which took place throughout the fieldwork period, were sometimes much longer than the formal interviews and provided a richer community context. They allowed researchers to gather information while interacting with the community at a practical level and contributed to a welcoming attitude (Gaudet, 2016) that allowed community members to be comfortable taking the role of information provider. The informal visits also helped to confirm information gathered in the formal interviews.

\section{Data Analysis}

Thematic analysis was used to identify patterns of meaning across the interview dataset. A flexible, inductive version of thematic analysis was used to identify patterns in both interviews and field notes and interpret them. The process began during data collection, when the researchers began to notice similar content and patterns between participants. The first author examined the entire data set, jotting down ideas for potential coding schemes from both the interviews and the field notes (Braun and Clarke, 2006). Once she was familiar with the dataset, she began to identify possible patterns and assign a code to each pattern.
Since there were no recorded interviews to transcribe, the notes from the interviews were elaborated upon instead and sometimes combined with field notes. Only a few key quotations were recorded verbatim during the interviews.

\section{RESULTS}

Throughout the interviews, visits, and fieldwork, community members spoke and shared stories about the place of traditional food in the community. A list of sub-themes was then created from the initial interview codes, which included tradition, traditional food, greenhouses, gardening, school, community ownership, school ownership, expansion, development, training, and feasibility. The sub-themes were later grouped under three main themes: tradition, ownership, and development. We use these themes to report our results on the genesis of the hoop house project.

\section{Tradition}

The hoop house was an attempt to integrate gardening into the community's subsistence strategy, so it was important that the project reflect local knowledge. Researchers were careful to become aware of local social and cultural structures to avoid a colonialist mind set. The values of progress, efficiency, and modernization of the colonial era are foreign to subsistence agriculture. Indeed, members of the community are simply seeking ways to bring good food into the community, and in doing so are operationalizing strategies of flexibility and land use. It has been shown that if community gardening is introduced in an inclusive and participatory way, Indigenous communities can incorporate this activity into their seasonal pattern of traditional subsistence practices (Loring and Gerlach, 2010). It is for this reason that the theme of tradition, including whether gardening has a place alongside traditional food, formed a key line of questioning. One participant, discussing the importance of food in the community, noted that people still enjoy attending community feasts where people share traditional foods they have procured with others. When asked about what was considered to be traditional food, most participants responded that it was any food that is hunted or fished. Community members listed moose, caribou, fish, beaver, goose, and other local species as being traditional foods. While plant foods did not come up in discussion immediately, most people did eventually mention that eating wild edible plants (e.g., blueberries) was also considered to be traditional. We did not attempt to grow any plants from the local ecosystem in the hoop house; however, all participants except one felt that food grown in the garden could be considered in line with traditional food since it was "from the land." Only one participant had the opinion that "food is just food" (Community participant, pers. comm. 2017). 
One of the women who worked in the hoop house explained that planting and watching the food grow gave her a feeling of being connected to the food, similar to the way she feels about more traditional land-based foods. Similarly, another participant expressed a clear affinity for food from the garden because she grew it herself. She made an important distinction between foods that she was able to grow, as opposed to vegetables she would buy in a can. Participants also spoke of cooking the vegetables from the hoop house along with traditional meats, as if to emphasize how food grown in the hoop house was aligned with the meat procured from the land. They explained that wild meat (especially moose) represented the most value in terms of traditional food, but it is often cooked with potatoes. If the potatoes were locally grown, people felt it would fit more closely with the wild meat. Responses such as these show that gardening initiatives can and should be linked to land food programs in the North under the guidance of community leadership. Growing food opens a space that can include traditional teachings and potentially offer a means to address food insecurity and dietary health concerns. These findings contribute to a body of research that seeks to understand how Indigenous gardening can be successful outside of the Western framework of economic development. Gardening can be integrated into traditional practices, and this research supports the idea that the line between "modern" and "traditional" food practices is increasingly blurred (Loring and Gerlach, 2010).

\section{Ownership}

As both the community and our funders viewed this project as a priority, in addition to a community project coordinator from the Band Office, two community members were hired as staff to tend to the gardens. Both were female, in their mid-twenties, and residents of Wapekeka First Nation, and they had no previous experience with gardening. Each replied to a job posting in the Band Office and signed contracts to work from May 2017 to September 2017. The primary responsibilities of the hoop house staff were to perform regular gardening upkeep, involve local youth in gardening activities, and attempt to harvest and distribute any vegetables produced. The first author instructed them briefly on planting and harvesting, although instruction was minimal. Demonstrating the practicality of simple gardening without intense training was an important factor for the long-term success of the project. Undertaking the project despite team inexperience was a purposeful attempt to demonstrate the feasibility of a hoop house in this context. The goal was to show that cultivating a simple garden for subsistence does not require sophisticated materials, training, or equipment and that being able to do so would foster a sense of ownership in our hoop house staff.

Constructing the hoop house structure was daunting without prior experience, but the second author was able to use previously established connections for assistance during the build. In addition to formal project members and the research team, local volunteers Sid, Derek, and Chris also provided invaluable support. The $12^{\prime} \times 32^{\prime}$ hoop house in the Wapekeka First Nation (Fig. 2) was constructed using lumber, PVC piping, and $6 \mathrm{~mm}$ plastic purchased and shipped from the Home Hardware Store in Sioux Lookout, approximately $450 \mathrm{~km}$ away. The structure was erected in the span of approximately 10 days by research team members, local volunteers and to a lesser extent, students from the elementary school. The hoop house construction was based on a plan designed by Alberta Home Gardening, with instructions on how to build it and materials required for assembly (Alberta Home Gardening, 2008). Raised garden beds were also built inside the structure (Fig. 3) to help keep insects away and to enable soil to thaw more quickly. Prior to the research team's arrival, our local volunteers were asked to determine what would be the best site to locate the hoop house.

Once the research team was on site, it became clear that finding a location would not be easy, as many factors needed to be taken into consideration. On the first day, the research team was presented with the options that were available. The first challenge was finding level land that was relatively free from permafrost and away from spring flooding. The site also had to be in direct sunlight for most of the day, ideally facing south to ensure optimal sun exposure. Access to water was another consideration. Without any other watering source, the hoop house needed to be near a public building to which a garden hose could be easily connected. Perhaps the most important consideration was visibility, which researchers categorized under the main theme of ownership. Placing the hoop house in a noticeable, well-lit, and open location would help to discourage vandalism, something that community members deemed highly likely. All of these factors were discussed with the project team and after much deliberation, as well as visits to potential sites, a location was finally chosen. The hoop house site is located between the gymnasium and the Wapekeka community store. The space is in full sunlight, highly visible, and close enough to the school so that the students can easily be involved in gardening activities. The structure was built close to the community store, a central hub for traffic in the community. Not only would this location discourage vandalism, but it also acted to showcase the various people involved in the project, including both volunteers and students aged 6-12. The plot of land was flat enough to start construction with little leveling and close enough to a drainage system that would help relieve spring flooding. The earth at the site would not be rich enough to grow plants, a problem that would be addressed later. With the location chosen after two days in the community, the next step was to implement our afterschool wellness program that would take place during the construction of the hoop house.

During the initial stages of construction, researchers spent part of each day in the Reverend Eleazar Winter Memorial Elementary School offering basic nutrition 


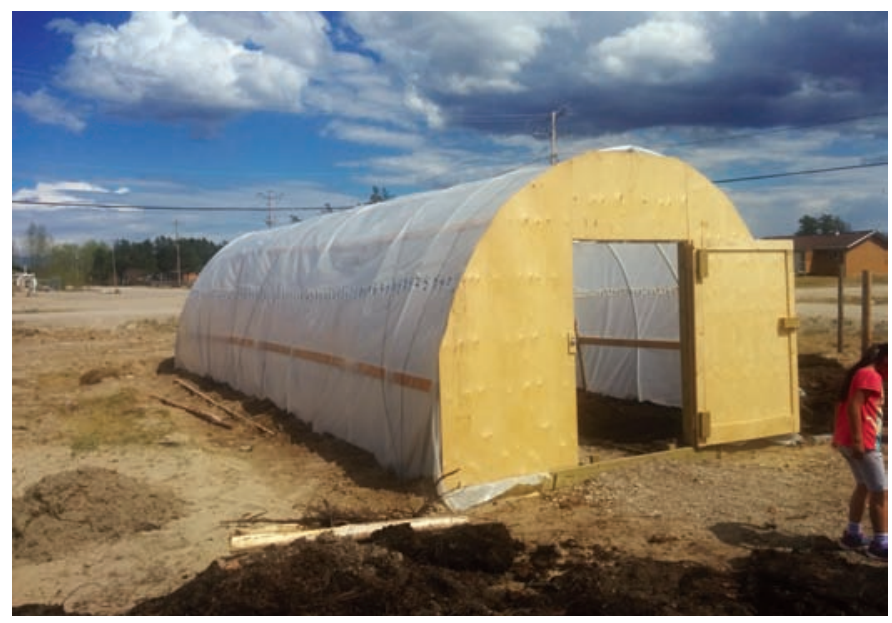

FIG. 2. Photograph of the hoop house at the end of construction. Photo credit: H.A. Thompson.

classes and introducing the children to the idea of gardening and greenhouses. At the outset of the project, community leadership made it clear that they wished to engage the school in the hoop house project as much as possible. Under the direction of the principal, the research team worked with students in the classroom not only to educate, but also to foster a sense of ownership and excitement about the hoop house project in the schoolchildren. The children were given the opportunity to provide input on what would be planted in the garden during the school workshops, and they were invited after school to help with simple gardening tasks such as weeding and raking. The children were also encouraged to continue to visit and help with the hoop house throughout the first growing season. It was believed that if local youth were interested and involved in the garden from the outset, they would respect and enjoy the hoop house throughout the growing season. During initial conversations about the project, community leaders and the local coordinator made it clear that youth should be actively involved in all stages of the project because of their concern that the hoop house structure would be vandalized.

Six interview participants noted that the hoop house was likely not destroyed over the summer because of the school's involvement with it. The staff repeatedly spoke about the students' curiosity and interest in the garden throughout the summer. One of the staff explained: "The kids were very interested in it, they would ask me to keep it unlocked so they could go play" (A. Nothiing, pers. comm. 2017). The involvement of the students in the garden made it a space where they felt connected and included, and it was that connection that discouraged harm and encouraged curiosity and appreciation. A second participant laughed and said, "I can't believe it is still standing!" She went on to explain that "I think the kids' involvement in the greenhouse is the reason it is still going" (D. Foxx, pers. comm. 2017). The moments when the youth were able to feel involved in the decision-making process, such as picking which foods to plant in the garden, were critical. Involving the students in this way ensured that they felt a sense of connection to

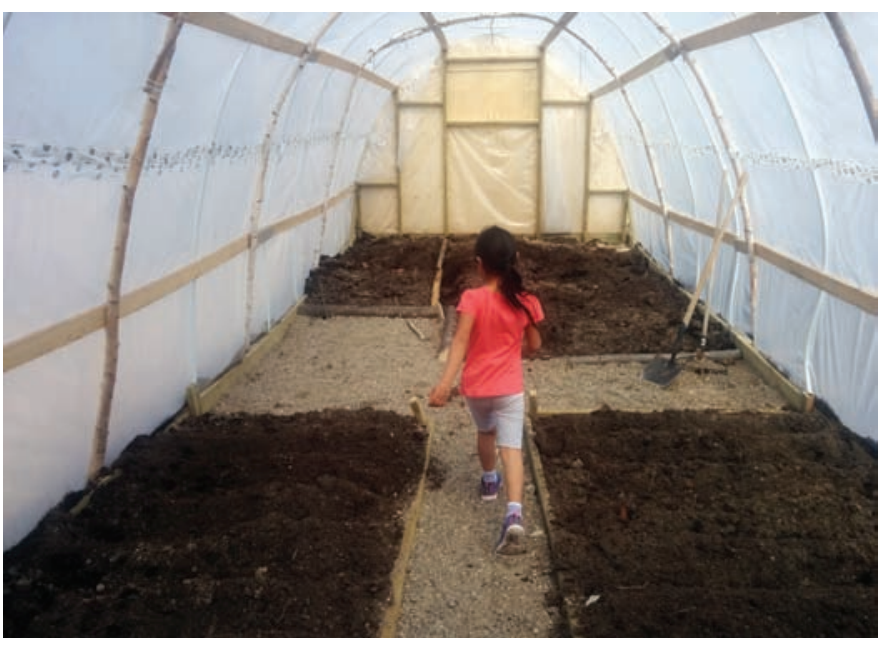

FIG. 3. Raised garden beds in the interior of the hoop house, along with a student from the Reverend Eleazar Winter Memorial School. Photo credit: H.A. Thompson.

the hoop house and some responsibility for what happened to the structure. This encouraged them to participate in gardening tasks, which fostered a sense of ownership once the hoop house was functioning.

We chose a simple, inexpensive, easy to build hoop house for a number of reasons. First, researchers knew that limiting costs was essential because funds were limited and shipping materials to this region would be costly: in fact, shipping costs exceeded the cost of materials. Second, the project team had little to no experience with construction, warranting a more modest approach not only for construction, but also for maintenance and operation. In comparison to a more complex structure, such as the polycarbonate one that Skinner et al. (2014) constructed at the Fort Albany First Nation, the hoop house structure was simple enough to be realistically completed and operated by inexperienced gardeners, with limited resources and within a narrow time frame. Because this initiative is a purposeful demonstration of feasibility, implementing a simple hoop house was categorized under the main theme of ownership. If community members felt that they had a great deal of control in the project design and implementation, they would feel as if it were their own. The local volunteers were involved in every aspect of project development, from deciding where the structure would be located in the community to being the primary ones responsible for its construction.

Although the design was relatively simple, constructing the hoop house was not an easy task. The second author initially took the lead to build the frame of the structure; however, local community members quickly noticed flaws in construction and the difficulties encountered in putting the frame together. One individual who had building skills offered to help, lending his time and equipment to the extent that he was primarily responsible for the hoop house construction. One reason for the difficulty in setting up the frame was that the supplier sent improper PVC piping that was not ridged enough to form the domed support for 
the structure. A proper frame needed to be made in order to support the plastic covering that would form the clear plastic roof of the hoop house. Without the time or money to solve the problem by getting the right materials, the main volunteer Sid, along with his brother Chris, devised a solution. They decided to substitute PVC pipes with birch saplings that could be carefully bent and tied together, creating makeshift supports for the roof. Through local ingenuity, a sturdy frame was built in a style that reflected more traditional methods of shelter construction often seen in teepees and lean-tos. This is just one example of how local involvement throughout the construction process proved to be invaluable and likely enhanced community ownership over the project. The second major challenge to be faced was acquiring nutrient-rich soil to fill the raised garden beds. In the original discussions about building a hoop house, it was explained that areas with rich black soil existed approximately $5 \mathrm{~km}$ from the community although they were difficult to access. A heavy equipment operator was hired to use a loader and backhoe to access the soil and have it shipped by truck to the garden. This situation delayed construction, since the rest of the structure could not be built until the soil was delivered. It took two days to retrieve and place the soil in the foundation of the hoop house garden beds.

The hoop house eventually consisted of two ends closed off with plywood, a domed skeleton made of both flexible PVC piping and arched birch saplings, and a covering of $6 \mathrm{~mm}$ plastic. The structure had a lockable door on one end and a small, hinged hatch for ventilation on the other. Inside temperatures were typically $10^{\circ} \mathrm{C}$ to $15^{\circ} \mathrm{C}$ warmer than the outside temperature in the spring and reached highs of almost $55^{\circ} \mathrm{C}$ in the summer. Without the option of opening the hatch to ventilate the hoop house, it would have been nearly impossible to work inside during the summer months and too hot for the plants to grow. With the hoop house construction finished, researchers and community volunteers still had logistical and operational challenges. Although the structure was close to the community gym, a practical means for watering the gardens had not yet been established. Researchers discussed several possible solutions to watering with the community partners, including a water barrel or hose access, but were unable to implement anything before they left the community. Before the research team departed, hoop house staff members were given the seeds and brief planting instructions. A document was prepared and given to staff about seed spacing and watering instructions. These instructions were also verbally explained to both of the staff members, who planted the seeds approximately one week after the research team left the community. Staff members were instructed to invite local youth to help with planting and to continue to teach basic gardening skills. Bush beans, snow peas, carrots, and radishes were planted in four raised garden beds inside the hoop house as per the students' request. The plants were spaced evenly according to the spacing instructions on the seed packets, and planted into four separate raised beds in even rows. The hoop house staff were left in charge for the spring and summer growing seasons.

From data collected during interviews, participant observation, and simply visiting the community, researchers attributed project success to two key aspects surrounding the idea of ownership. One of the important messages shared by community members was that in order for a project like this to work, it must allow for mutual creation of project ideas and an equally shared opportunity to implement those ideas, including ways to solve problems. Initiating a project that was co-created, and often led entirely by local volunteers, created a sense of community ownership. Community involvement was critical at several stages. The local project coordinator initially came up with the idea of a greenhouse-like hoop house, and separate local parties volunteered their time during its construction. Throughout the process, the entire community was able to watch local involvement of youth and volunteers, particularly during the construction phase. It was clear that the researchers were not a foreign party with a highly skilled construction team; community members could watch as they encountered building challenges and ultimately step in, help resolve issues, and eventually help lead the process. Researchers made it clear they were inexperienced from the start, maintained an open dialogue with everyone, and relied on local help and knowledge to complete the project.

In fact, the construction process was so much in the hands of local volunteers that several of them noted that it was much easier than anticipated. During an interview, Sid, one of our main volunteers, said that "it was straightforward and easy, except we had to improvise a lot." He went on to say that "the hardest part was starting it, I think that I would like to try and build one for my family" (S. Anderson, pers. comm. 2017). The idea to integrate the hoop house project with nutrition and gardening workshops also came from the community. Community members understood how a project like this would work in the Wapekeka First Nation and rightly pointed to the students or youth as a means to develop further community ownership over the project. Other research with Indigenous youth has repeatedly demonstrated that their involvement is imperative to project uptake and success (Forsyth and Heine, 2008; Mason and Koehli, 2012; Petrucka et al., 2016), and we similarly recognized that youth involvement would be key to developing connection and responsibility, as well as to promoting sustainability in future projects in Wapekeka or other First Nations in the region.

\section{Development}

Future development of the hoop house would largely be directed by what happened during the summer months when the researchers were absent from the community, and subsequently by what they observed during their return trip in September. Therefore, this final section is centered on the main theme of development. Throughout 
the growing season, the research team maintained regular communication with the hoop house staff, who regularly sent narrative and pictorial updates via social media. It was apparent from the pictures that youth were actively involved in planting the seeds, but it was less apparent how active they were in weeding and watering the garden. Despite several suggestions, a solution to easier watering had not been found, and the hoop house staff were carrying $4 \mathrm{~L}$ jugs of water from the nearby lake to water the seeds. This was very labor intensive and clearly not an ideal solution, but the staff did their best to ensure the success of the garden. Approximately four weeks after the seeds were planted, the hoop house staff started to send pictures of the plants beginning to grow via e-mail and social media. It was noticeable that while some plants were thriving, others were not growing properly. Pictures were sent of some vegetables being picked and distributed to the children who happened to be at the hoop house that day. It gradually became apparent that the hoop house staff were doing their best to keep watering the garden, but there was little evidence that other forms of gardening maintenance were being performed. It was encouraging to see the hardier vegetables growing, but clearly more work was required if the garden was to produce anywhere close to its potential capacity.

When research team members returned in midSeptember, the hoop house was hot and humid in spite of the fall weather. Despite limited resources and fears that the hoop house would be damaged or destroyed, the structure was still standing after the summer growing season. Inside the hoop house, however, weeds were overgrown, and the soil was dry; peas on the vine had ripened and waned, with new ones growing over the withered ones. There were carrots and radishes that had ripened and then rotted, left untouched or unnoticed in the garden beds. But despite this, a number of vegetables had grown. Both hoop house staff exhibited surprise about how easy it was to grow vegetables, and each expressed the desire to undergo future training. The idea of future training was included in the main theme of development. They were so pleased about being modestly successful at gardening in the pilot year that one of the women said that she "would do it in other years, even for free" (A. Nothiing, pers. comm. 2017). The hoop house staff successfully grew peas, beans, radishes, and carrots that were ready for harvest. The structure provided the necessary shelter for the plants to grow, and there was enough community interest to keep the garden plots going. At one point during the summer, the primary volunteer set up a makeshift lattice built of branches to help support the growth of the peas. The successes that were achieved with limited resources and support were something to celebrate with the students at the school. Local youth were invited to participate in the final harvest, and both the youth and the hoop house staff were keen to participate (Fig. 4).

The students were instructed to dig around in the garden and set aside any vegetables that they found, and then discard any non-vegetables. Altogether, four gallon-sized

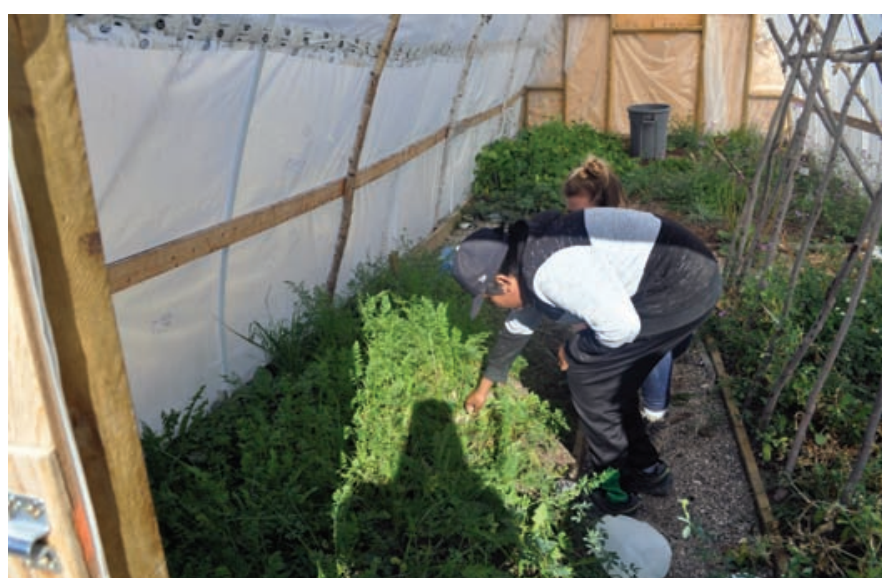

FIG. 4. H. Thompson and a student picking peas during the final harvest. Photo credit: C.W. Mason.

bags of carrots, peas, bush beans, and radishes were harvested. The students were also liberally eating the vegetables straight from the garden with excitement. They had never before seen fresh vegetables from a garden, and many had questions about what was being picked, what was edible, and what certain plants tasted like. At one point, approximately 10 youth filled the hoop house, excited by what their garden had produced and taking part in picking the vegetables. It took approximately two hours to pick and sort the vegetables, which were then washed and placed in Ziploc bags. The vegetables were then given to the school to be distributed for snacks. Once all the vegetables were harvested from the garden, the remaining plants and weeds were removed and the ground turned over with rakes and shovels. The garden beds were then built up with lumber and $\operatorname{logs}$ to help increase the soil depth for the following year.

Three of the four garden beds were covered in cardboard for the winter, while the remaining garden bed was used for a final lesson with the students. Planting garlic in the fall is often recommended as the bulbs are frost tolerant and earlier planting will yield bigger and more flavorful bulbs the following summer. The aim is to give a long enough period before the ground freezes for the plant to develop roots, but not enough time for it to form top growth before freezing temperatures. Plans for garlic planting were identified as another teaching opportunity that could be used to gauge continued interest in the garden. Researchers again visited classrooms to teach a lesson about garlic and to invite the students to the hoop house to plant the bulbs. The garlic planting session was highly successful, as it was clear that the students were still interested in the hoop house and eager to help. Getting the youth out to the hoop house months later was an encouraging demonstration of continued interest. Approximately eight students showed up after school to help plant about 30 to 40 garlic cloves. The garlic bed was uncovered, and researchers were left to wait with the hope that spring flooding would leave the bulbs intact. Preparing the hoop house in any way possible and using garlic to keep the children interested in the garden for 
the subsequent year were part of our development strategy. The research team is happy to report that additional funding was secured for the 2018 growing season. Our aims for the future are to improve the hoop house structure that was built with limited resources, construct better raised garden beds inside the hoop house, develop a more efficient watering system, and start seedlings indoors so a broader range of vegetables can be planted. Adjacent to the hoop house structure, a garden plot will be developed where hardier vegetables such as potatoes will be planted. One of the main features of the program will again be to involve the schoolchildren in all stages of planting and hoop house development. It will be essential to continually involve as many youth and community members as possible to ensure the future success of the hoop house project.

The importance of community involvement during implementation was undoubtedly essential; however, equally significant is the longstanding partnership between the community and the research team, which we will continue to foster. Community members were comfortable approaching members of the research team to offer advice or to provide feedback on how to develop the project in the future, especially so that it has broader reach within the community. In each of the interviews or conversations, participants responded favourably to the idea of expanding the project and offered recommendations for moving forward. Many participants suggested that having more public presentations (in person and over the local radio station) at the outset of the project would have increased awareness about what the hoop house was for and encouraged more community involvement. Other recommendations included building a more efficient watering system, hiring more support staff, providing more training for staff members, and building larger garden beds. Another interesting suggestion was to connect the gardening project to the existing land-based food and traditional teaching initiatives in the community. Derek, a longstanding community food champion, runs a program to take school-aged youth onto the land to learn about traditional practices. Linking the hoop house project to this program would further connect the garden to local food practices and assist with project sustainability.

One of the main questions surrounding the hoop house under the theme of development was how much impact it could have on improving local food security. While there were many positive outcomes of the project, such as engaging youth, increasing local knowledge of gardening, and demonstrating community capacity, considerably more investment in the hoop house and its potential vegetable production would be necessary to even begin to have an impact on daily dietary needs. If the raised garden beds produced at full capacity, there still would not be enough vegetable production to feed the whole community for even a short period of time. However, the project illustrates that even the simplest of greenhouse-like structures can extend growing seasons by two to three weeks on either end (spring and later summer), and that communities could supplement (if only seasonally) vegetable intake through local gardening. In addition to the actual food production, the hoop house project produced a sense of accomplishment and interest among project staff and volunteers, and perhaps most importantly, local youth. At the core of food sovereignty initiatives is a set of objectives based on strengthening community and increasing social and environmental sustainability in the production, consumption, and distribution of nutritious and culturally appropriate food (Desmarais and Wittman, 2014). Thus, food sovereignty was included under the main theme of development. The hoop house project was most concerned with simply bringing healthy food into the community in a food security framework. However it did offer steps for regaining control over food efforts that were disrupted by colonialism. Indeed, the outcomes of the project are larger than food intake. Food sovereignty in Canada stresses the importance of decolonization and self-determination, and including local gardening efforts in this framework in an inclusive, collaborative, and culturally appropriate way can fit the food sovereignty paradigm and strengthen community efforts towards increasing autonomy. This hoop house is not a solution in itself, but it does offer a potential strategy for developing initiatives that combat food insecurity, and in the process, foster an interest in nutritious food, local food production, and the possibility of building grassroots solutions to address health challenges.

\section{CONCLUSION}

The success and sustainability of many Indigenous health and food initiatives have been correlated with the presence of and connection to program champions (O’Loughlin et al., 1998; Scheirer, 2005; Skinner et al., 2014), and this project is no exception. Identifying existing action-oriented community members and involving them throughout the project was an important step towards establishing the hoop house project. This study described only one growing season and did not have high enough yield to assess its potential impact on community energy needs. However, these successes indicate that with proper care and motivation and a firmly established gardening and harvesting routine, the project could indeed assist in making fresh vegetables more readily available to community members. Knowledge gained during this initial phase will be valuable for future growing seasons. While it is beyond the scope of this paper to study the long-term outcomes of the hoop house project in the Wapekeka First Nation, future research regarding hoop house gardening could examine some outcomes regarding the knowledge and skills students gain in nutrition and gardening programming. Findings could have important relevance for future projects and programs addressing food security issues.

The inflated costs of market food, limited availability of nutritious foods, and lack of government support for nutritious food programs in the North are the primary 
reasons for food insecurity in northern Indigenous communities (Skinner et al., 2006). The results of our project indicate that small hoop house, greenhouse, and gardening initiatives in the North are a simple micro-piece of the solution to food insecurity. Part of what they offer is less the tangible relief of hunger than a positive space for strengthening partnerships, producing innovation, and creating local food champions.

\section{ACKNOWLEDGEMENTS}

We wish to thank the Wapekeka First Nation leadership, hunters, and food champions who made this research possible. We would also like to thank the Michaëlle Jean Centre for Global and Community Engagement and Mitacs, a Canadian organization that links industry and academia to promote research and innovation for their financial support.

\section{REFERENCES}

Ablah, E., Brown, J., Carroll, B., and Bronleewe, T. 2016. A community-based participatory research approach to identifying environmental concerns. Journal of Environmental Health 79(5):14-19.

Alberta Home Gardening. 2008. How to build an inexpensive hoop-style greenhouse.

http://www.albertahomegardening.com/how-to-build-aninexpensive-hoop-style-greenhouse/

Alfred, T. 2009. Wasáse: Indigenous pathways of action and freedom. Toronto: University of Toronto Press.

___ 2009. Colonialism and state dependency. Journal de la santé autochtone 5:42-60.

Barbeau, C.D., Oelbermann, M., Karagatzides, J.D., and Tsuji, L.J.S. 2015. Sustainable agriculture and climate change: Producing potatoes (Solanum tuberosum 1.) and bush beans (Phaseolus vulgaris 1.) for improved food security and resilience in a Canadian subarctic First Nations community. Sustainability 7(5):5664-5681.

https://doi.org/10.3390/su7055664

Batal, M., Gray-Donald, K., Kuhnlein, H., and Receveur, O. 2005. Estimation of traditional food intake in Indigenous communities in Denendeh and the Yukon. Journal of Circumpolar Health 1(64):46-54.

Bersamin, A., Zidenberg-Cherr, S., Stern, J.S., and Luick, B.R. 2007. Nutrient intakes are associated with adherence to a traditional diet among Yup'ik Eskimos living in remote Alaska Native communities: The CANHR Study. International Journal of Circumpolar Health 66(1):62-70. https://doi.org/10.3402/ijch.v66i1.18228

Braun, V., and Clarke, V. 2006. Using thematic analysis in psychology. Qualitative Research in Psychology 3(2):77-101. https://doi.org/10.1191/1478088706qp063oa
Brinkman, T.J., Hansen, W.D., Chapin, F.S., III, Kofinas, G., BurnSilver, S., and Rupp, T.S. 2016. Arctic communities perceive climate impacts on access as a critical challenge to availability of subsistence resources. Climatic Change 139(34):413-427.

https://doi.org/10.1007/s10584-016-1819-6

Chrisjohn, R.D., and Young, S.L. 1997. Among school children: Psychological imperialism and the residential school experience in Canada. In: Chrisjohn, R.D., and Young, S.L., eds. The circle game: Shadows and substance in the Indian residential school experience in Canada. Penticton, British Columbia: Theytus Books. Appendix E.

Coxall, M. 2014. Ethical eating: A complete guide to sustainable food. Andalusia, Spain: Cornelio Books.

Czyzewski, K. 2011. Colonialism as a broader social determinant of health. International Indigenous Policy Journal 2(1): Article 5. https://doi.org/10.18584/iipj.2011.2.1.5

Damman, S., Eide, W.B., and Kuhnlein, H.V. 2008. Indigenous peoples' nutrition transition in a right to food perspective. Food Policy 33(2):135-155. https://doi.org/10.1016/j.foodpol.2007.08.002

Desmarais, A., and Wittman, H. 2014. Farmers, foodies and First Nations: Getting to food sovereignty in Canada. The Journal of Peasant Studies 41(6):1153-1173. https://doi.org/10.1080/03066150.2013.876623

DeWalt, K.M., and DeWalt, B.R. 2002. Participant observation: A guide for fieldworkers: Walnut Creek, California: Altamira Press.

Elliott, B., Jayatilaka, D., Brown, C., Varley, L., and Corbett, K.K. 2012. "We are not being heard": Aboriginal perspectives on traditional foods access and food security. Journal of Environmental and Public Health 2012: 130945. https://doi.org/10.1155/2012/130945

Fieldhouse, P., and Thompson, S. 2012. Tackling food security issues in Indigenous communities in Canada: The Manitoba experience. Nutrition \& Dietetics 69(3):217-221. https://doi.org/10.1111/j.1747-0080.2012.01619.x

Fletcher, C. 2003. Community-based participatory research relationships with Aboriginal communities in Canada: An overview of context and process. Pimatisiwin: A Journal of Aboriginal \& Indigenous Community Health 1(1):27-61.

Ford, J.D. 2009. Vulnerability of Inuit food systems to food insecurity as a consequence of climate change: A case study from Igloolik, Nunavut. Regional Environmental Change 9(2):83-100.

Forsyth, J., and Heine, M. 2008. Sites of meaning, meaningful sites? Sport and recreation for Aboriginal youth in inner city Winnipeg, Manitoba. Native Studies Review 17(2):99-113.

Frerichs, L., Hassmiller Lich, K., Dave, G., and Corbie-Smith, G. 2016. Integrating systems science and community-based participatory research to achieve health equity. American Journal of Public Health 106(2):215-222. https://doi.org/10.2105/AJPH.2015.302944 
Gaudet, J.C. 2016. An indigenous methodology for coming to know milo pimatisiwin as land-based initiatives for Indigenous youth. PhD thesis, University of Ottawa. Ottawa, Ontario. https://doi.org/http://dx.doi.org/10.20381/ruor-518

Haman, F., Fontaine-Bisson, B., Batal, M., Imbeault, P., Blais, J.M., and Robidoux, M.A. 2010. Obesity and type 2 diabetes in northern Canada's remote First Nations communities: The dietary dilemma. International Journal of Obesity 34(Suppl. 2):S24-S31.

https://doi.org/10.1038/ijo.2010.236

Indigenous and Northern Affairs Canada. 2017a. First Nation profiles interactive map.

http://cippn-fnpim.aadnc-aandc.gc.ca/index-eng.html

___ 2017b. Population characteristics.

http://fnp-ppn.aandc-aadnc.gc.ca/fnp/Main/Search/ FNPopulation.aspx?BAND NUMBER=206\&lang=eng

Jagosh, J., Bush, P.L., Salsberg, J., Macaulay, A.C., Greenhalgh, T., Wong, G., Cargo, M., Green, L.W., Herbert, C.P., and Pluye, P. 2015. A realist evaluation of community-based participatory research: Partnership synergy, trust building and related ripple effects. BMC Public Health 15: 725.

https://doi.org/10.1186/s12889-015-1949-1

Krech, S., III, ed. 1984. The Subarctic fur trade: Native social and economic adaptations. Vancouver: UBC Press.

Kroll-Zeldin, O. 2016. Colonialism. Oxford Bibliographies. http://www.oxfordbibliographies.com/view/document/obo9780199766567/obo-9780199766567-0139.xml;jsessionid $=501$ 2563FE9D5D2DBEB7244C67E5E8970

Kuhnlein, H.V., and Receveur, O. 1996. Dietary change and traditional food systems of Indigenous peoples. Annual Review of Nutrition 16(1):417-442.

https://doi.org/10.1146/annurev.nu.16.070196.002221

Lambden, J., Receveur, O., Marshall, J., and Kuhnlein, H.V. 2006. Traditional and market food access in Arctic Canada is affected by economic factors. International Journal of Circumpolar Health 65(4):331 - 340.

Leblanc, J., and Burnett, K. 2017. What happened to Indigenous food sovereignty in northern Ontario: Imposed political, economic, socio-ecological, and cultural systems changes. In: Robidoux, M.A., and Mason, C.W., eds. A land not forgotten: Indigenous food security and land-based practices in northern Ontario. Winnipeg: University of Manitoba Press. 18-41.

Leibovitch Randazzo, M.P., and Robidoux, M.A. 2018. The costs of local food procurement in a northern Canadian First Nation community: An affordable strategy to food security? Journal of Hunger \& Environmental Nutrition. Published online 27 April 2018.

https://doi.org/10.1080/19320248.2018.1464998

Lombard, K.A., Forster-Cox, S., Smeal, D., and O'Neill, M.K. 2006. Diabetes on the Navajo nation: What role can gardening and agriculture extension play to reduce it? Rural and Remote Health 6(4): 640.

Loring, P.A., and Gerlach, C. 2010. Food security and conservation of Yukon River salmon: Are we asking too much of the Yukon River? Sustainability 2(9):2965-2987.

https://doi.org/10.3390/su2092965
Mason, C., and Koehli, J. 2012. Barriers to physical activity for Aboriginal youth: Implications for community health, policy, and culture. Pimatisiwin 10(1):97-107.

McHugh, T.-L.F., and Kowalski, K.C. 2009. Lessons learned: Participatory action research with young Aboriginal women. Pimatisiwin 7(1):117-131.

McHugh, T.-L. F., Coppola, A.M., and Sinclair, S. 2013. An exploration of the meanings of sport to urban Aboriginal youth: A photovoice approach. Qualitative Research in Sport, Exercise and Health 5(3):291 - 311. https://doi.org/10.1080/2159676X.2013.819375

Miller, J.R. 1996. Shingwauk's vision: A history of Native residential schools. Toronto: University of Toronto Press.

Milloy, J.S. 1999. A national crime: The Canadian government and the residential school system, 1879 to 1986. Manitoba Studies in Native History 11. Winnipeg: University of Manitoba Press.

Morrison, D. 2011. Indigenous food sovereignty: A model for social learning. In: Wittman, H., Desmarais, A., and Wiebe, N., eds. Food sovereignty in Canada: Creating just and sustainable food systems. Halifax: Fernwood Publishing. 97-113.

O’Loughlin, J., Renaud, L., Richard, L., Sanchez Gomez, L., and Paradis, G. 1998. Correlates of the sustainability of community-based heart health promotion interventions. Preventative Medicine 27(5):702-712. https://doi.org/10.1006/pmed.1998.0348

Ortlipp, M. 2008. Keeping and using reflective journals in the qualitative research process. The Qualitative Report 13(4):695-705.

Our Food in Nunavut. 2015. NiKigijavut Nunatsiavutinni (Our Food in Nunatsiavut) Project.

https://www.itk.ca/nuluaq-mapping-project/initiative/ nikigijavut-nunatsiavutinni-our-food-in-nunatsiavut-project/

Paci, C.D.J., Dickson, C., Nickels, S., Chan, L., and Furgal, C. 2004. Food security of northern Indigenous peoples in a time of uncertainty. In: 3rd Northern Research Forum Open Meeting. $11 \mathrm{p}$.

Pal, S., Haman, F., and Robidoux, M.A. 2013. The costs of local food procurement in two northern Indigenous communities in Canada. Food and Foodways 21(2):132-152.

https://doi.org/10.1080/07409710.2013.792193

Petrucka, P.M., Bickford, D., Bassendowski, S., Goodwill, W., Wajunta, C., Yuzicappi, B., Hackett, P., Jeffery, B., and Rauliuk, M. 2016. Positive leadership, legacy, lifestyles, attitudes, and activities for Aboriginal youth: A wise practices approach for positive Aboriginal youth futures. International Journal of Indigenous Health 11(1):177-197. https://doi.org/10.18357/ijih111201616017

Power, E.M. 2008. Conceptualizing food security for Aboriginal people in Canada. Canadian Journal of Public Health 99(2):95-97.

Robidoux, M.A., and Mason, C.W., eds. 2017. A land not forgotten: Indigenous food security \& land-based practices in northern Ontario. Winnipeg: University of Manitoba Press. 
Robidoux, M.A., Batal, M., ImbeauIt, P., Seabert, T., Blais, J.M., Pal, S., Krümmel, E.M., and Haman, F. 2012. Traditional foodways in two contemporary northern First Nations communities. The Canadian Journal of Native Studies 32(1):59-77.

Rudolph, K.R., and McLachlan, S.M. 2013. Seeking Indigenous food sovereignty: Origins of and responses to the food crisis in northern Manitoba, Canada. Local Environment 18(9):1079-1098. https://doi.org/10.1080/13549839.2012.754741

Russo, V.M., and Shrefler, J. 2012. Bunching onion culture in greenhouse and hoop house. HortScience 47(11):1564-1568.

Samson, C., and Pretty, J. 2006. Environmental and health benefits of hunting lifestyles and diets for the Innu of Labrador. Food Policy 31(6):528-553.

https://doi.org/10.1016/j.foodpol.2006.02.001

Scheirer, M. 2005. Is sustainability possible? A review and commentary on empirical studies of program sustainability. American Journal of Evaluation 26(3):320-347. https://doi.org/10.1177/1098214005278752

Seabert, T., Pal, S., Krümmel, E.M., Blais, J.M., Imbeault, P., Robidoux, M.A., and Haman, F. 2013. Dietary practices in isolated First Nations communities of northern Canada: Combined isotopic and lipid markers provide a good qualitative assessment of store-bought vs locally harvested foods consumption. Nutrition \& Diabetes 3(10), e92. https://doi.org/10.1038/nutd.2013.34

Simpson, L.B. 2014. Land as pedagogy: Nishnaabeg intelligence and rebellious transformation. Decolonization: Indigeneity, Education \& Society 3(3):1-25.

Skinner, K., Hanning, R.M., and Tsuji, L.J.S. 2006. Barriers and supports for healthy eating and physical activity for First Nation youths in northern Canada. International Journal of Circumpolar Health 65(2):148-161.

Skinner, K., Hanning, R.M., Desjardins, E., and Tsuji, L.J.S. 2013. Giving voice to food insecurity in a remote indigenous community in subarctic Ontario, Canada: Traditional ways, ways to cope, ways forward. BMC Public Health 13: 427. https://doi.org/10.1186/1471-2458-13-427

Skinner, K., Hanning, R.M., Metatawabin, J., and Tsuji, L.J.S. 2014. Implementation of a community greenhouse in a remote, sub-Arctic First Nations community in Ontario, Canada: A descriptive case study. Rural and Remote Health 14(2): 2545.

Socha, T., Zahaf, M., Chambers, L., Abraham, R., and Fiddler, T. 2012. Food security in a northern First Nations community: An exploratory study on food availability and accessibility. Journal of Aboriginal Health 8(2):5-14.

Spiegelaar, N.F., and Tsuji, L.J.S. 2013. Impact of Euro-Canadian agrarian practices: In search of sustainable import-substitution strategies to enhance food security in subarctic Ontario, Canada. Rural and Remote Health 13(2): 2211.

Stanley, D., Marshall, Z., Lazarus, L., LeBlanc, S., Heighton, T., Preater, B., and Tyndall, M. 2015. Harnessing the power of community-based participatory research: Examining knowledge, action, and consciousness in the PROUD Study. Social Work in Public Health 30(3):312-323.

https://doi.org/10.1080/19371918.2014.1001935
Streit, D., and Mason, C.W. 2017. Traversing the terrain of indigenous land-based education: Connecting theory to program implementation. In: Robidoux, M.A., and Mason, C.W., eds. A land not forgotten: Indigenous food security \& land-based practices in northern Ontario. Winnipeg: University of Manitoba Press. $101-147$.

Stroink, M.L., and Nelson, C.H. 2009. Aboriginal health learning in the forest and cultivated gardens: Building a nutritious and sustainable food system. Journal of Agromedicine 14(2):263-269.

https://doi.org/10.1080/10599240902739737

Townsend, C.K.M., Dillard, A., Hosoda, K.K., Maskarinec, G.G., Maunakea, A.K., Yoshimura, S.R., Hughes, C., Palakiko, D.-M., Kehauoha, B.P., and Kaholokula, J.K. 2015. Community-based participatory research integrates behavioral and biological research to achieve health equity for native Hawaiians. International Journal of Environmental Research and Public Health 13(1): 4. https://doi.org/10.3390/ijerph13010004

Uusitalo, U., Sobal, J., Moothoosamy, L., Chitson, P., Shaw, J., Zimmet, P., and Tuomilehto, J. 2005. Dietary Westernisation: Conceptualisation and measurement in Mauritius. Public Health Nutrition 8(6):608-619. https://doi.org/10.1079/PHN2004716

Viola, A. 2006. Evaluation of the Outreach School Garden Project: Building the capacity of two Indigenous remote school communities to integrate nutrition into the core school curriculum. Health Promotion Journal of Australia 17(3):233-239.

Walch, A., Bersamin, A., Loring, P., Johnson, R., and Tholl, M. 2018. A scoping review of traditional food security in Alaska. International Journal of Circumpolar Health 77(1): 1419678. https://doi.org/10.1080/22423982.2017.1419678

Wesche, S.D., and Chan, H.M. 2010. Adapting to the impacts of climate change on food security among Inuit in the western Canadian Arctic. EcoHealthy 7(3):361 - 373. https://doi.org/10.1007/s10393-010-0344-8

Whiting, L.S. 2008. Semi-structured interviews: Guidance for novice researchers. Nursing Standard 22(23):35-40. https://doi.org/10.7748/ns2008.02.22.23.35.c6420

Willows, N.D. 2005. Determinants of healthy eating in Aboriginal peoples in Canada: The current state of knowledge and research gaps. Canadian Journal of Public Health 96(Suppl. 3):S32-S36.

Willows, N.D., Veugelers, P., Raine, K., and Kuhle, S. 2009. Prevalence and sociodemographic risk factors related to household food security in Aboriginal peoples in Canada. Public Health Nutrition 12(8):1150-1156. https://doi.org/10.1017/S1368980008004345

WHO (World Health Organization). 1996. Rome declaration on world food security and world food summit plan of action. Rome: WHO. http://www.fao.org/docrep/003/w3613e/w3613e00.HTM 